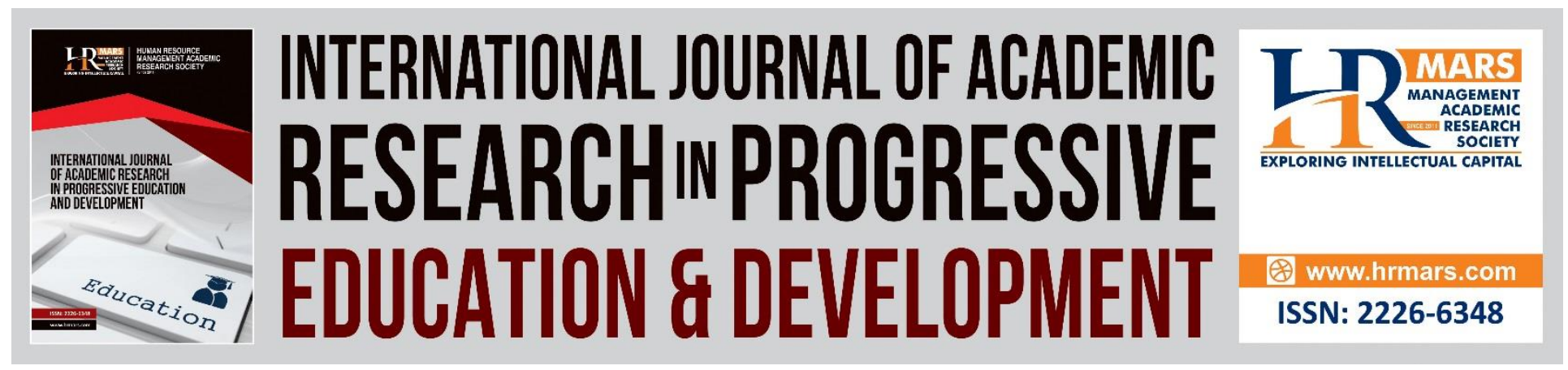

\title{
A Conceptual Framework: The Integration of SQ3R in Flipped Classroom Model for Chinese Reading Comprehension
}

\author{
Chew Moi Fong, Ng Miew Hoon
}

To Link this Article: http://dx.doi.org/10.6007/IJARPED/v9-i2/7484

DOI:10.6007/IJARPED/v9-i2/7484

Received: 17 March 2020, Revised: 20 April 2020, Accepted: 18 May 2020

Published Online: 28 June 2020

In-Text Citation: (Fong \& Hoon, 2020)

To Cite this Article: Fong, C. M., \& Hoon, N. M. (2020). A Conceptual Framework: The Integration of SQ3R in Flipped Classroom Model for Chinese Reading Comprehension. International Journal of Academic Research in Progressive Education and Development, 9(2), 421-431.

Copyright: (C) 2020 The Author(s)

Published by Human Resource Management Academic Research Society (www.hrmars.com)

This article is published under the Creative Commons Attribution (CC BY 4.0) license. Anyone may reproduce, distribute, translate and create derivative works of this article (for both commercial and non-commercial purposes), subject to full attribution to the original publication and authors. The full terms of this license may be seen at: http://creativecommons.org/licences/by/4.0/legalcode

\section{Vol. 9(2) 2020, Pg. 421 - 431}

Full Terms \& Conditions of access and use can be found at http://hrmars.com/index.php/pages/detail/publication-ethics 


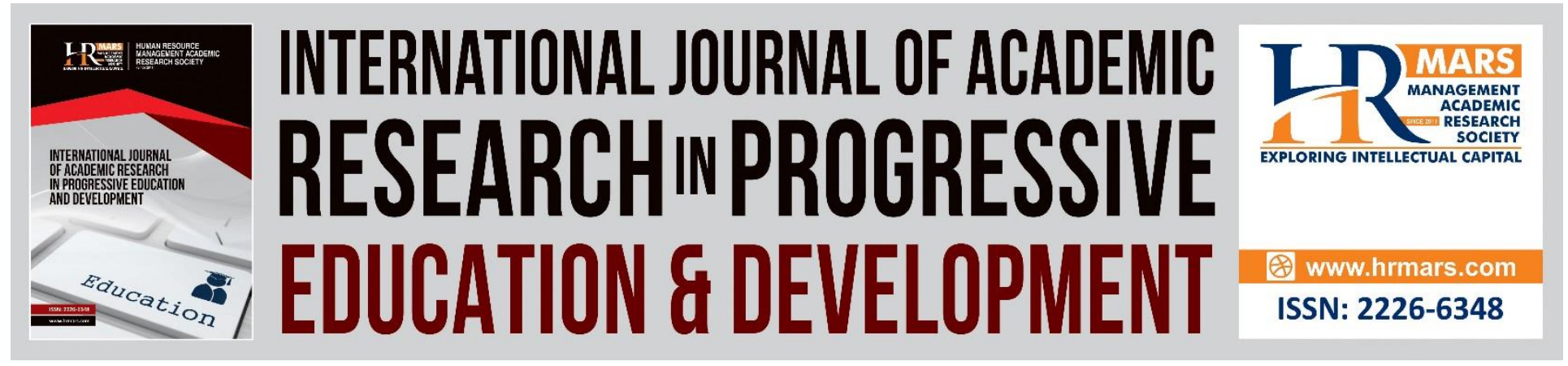

\title{
A Conceptual Framework: The Integration of SQ3R in Flipped Classroom Model for Chinese Reading Comprehension
}

\author{
Chew Moi Fong, Ng Miew Hoon \\ Modern Language Department, Faculty of Languages and Communication, Universiti \\ Pendidikan Sultan Idris, 35900 Tanjong Malim, Perak.
}

\begin{abstract}
Reading comprehension is one of the important elements in reading skills. Through reading comprehension, students will be able to know the meaning and gain the main information from the reading materials. An effective reading strategy will be a better way to help students understand more about reading. Meanwhile, internet technology is widely used in the education field to promote learning that occurs in the flipped model.
\end{abstract}

This study presents a practical teaching strategy to integrate the SQ3R reading strategy with the help of technology under a new teaching model. Literature reviews on reading comprehension, SQ3R strategy and flipped classroom model are also presented in this paper. This study will employ quantitative approach using surveys technique. Total of 118 year four students from three different primary school in Klang district will be involved in this survey research. A questionnaire and structured interview will be carried out to examine the students' perception toward the integration of SQ3R in Flipped Classroom Model for Chinese reading comprehension.

The primary aim of this study is to promote the Chinese reading comprehension learning process using SQ3R strategy in the flipped classroom teaching model. Through the proposed framework in this study, the SQ3R strategy in the flipped classroom model can be applied in the pedagogical practice. Therefore, this study should be valuable to researchers to present future studies and teachers who wish to improve their teaching methods.

Keywords: Chinese Language, Reading Comprehension, Reading Strategy, Sq3r, Google Classroom, Flipped Classroom Model.

\section{Introduction}

Reading is a crucial skill to expand students' knowledge. To gain meaning from reading materials, students need the ability to interpret the meaning. Reading comprehension is one of the elements of reading skills in order to stimulate thinking skills. Hans \& Hans (2015) define reading comprehension as the capacity and ability to comprehend a text. Comprehension is the 
interpretation of meaning from the written word and how they convey the knowledge from the reading.

Reading comprehension is considered as the highest level in the reading hierarchy (Singh \& Mishra, 2016). Therefore, comprehension skill is not easy to be mastered especially the students in primary school. This is also a major challenge for students. Students' performance in Chinese reading comprehension can be assessed from the result of Primary School Assessment Examination (UPSR). According to the 2017 UPSR result that showed the average performance of Chinese reading comprehension was $89.9 \%$ but the total percentage of students achieving Grade A was only $17.6 \%$. This result was slightly lower than the Chinese Essay which has the percentage of students who get A was $24.8 \%$ (Zhang, 2017). It means more students get distinction in Chinese essay rather than Chinese reading comprehension. This finding concludes that Chinese reading comprehension still needs improvement.

Apart from that, most of the students are lack of reading strategy and passive in learning (Wang, 2018). This is due to the reading lesson still teacher-centered (Luo, 2018). The students are overwhelmed with a lot of information. Besides, they are also not taught in proper and effective reading strategies. Reading strategy is very important for the students to learn themselves instead of relying on their teacher. There are various reading strategy and SQ3R is a popular strategy used in learning reading comprehension (Pamungkas \& Suhardi, 2019). Effective reading comprehension learning needs to be integrated with a reading strategy to enhance student in reading comprehension while developing higher-level of mind thinking.

Furthermore, the widespread use of technology in pedagogical practice makes learning more interesting. The $Z$ generation born in the early 2000s has the advantage and familiar with the technologies which have developed rapidly (Abdullah \& Mamat, 2018). By integrating technology in learning, the traditional teaching model had to be adjusted and transformed. Flipped classroom model has emerged as a powerful platform for teachers who want to change their conventional teaching method into more active learning (Chew, Jones, \& Wordley, 2018). This is in line with current educational trends to promote 21 st-century learning.

Thus, to improve students' reading comprehension skills, the teachers need to implement the SQ3R strategy with the Flipped Classroom model. It is a dynamic and active learning process that can support student-centered learning.

\section{Literature Review}

This section of the article will discuss the related literature of the reading comprehension, SQ3R strategy and Flipped Classroom Model.

\section{Reading Comprehension}

According to Santi and Reed (2015), reading comprehension is a complex cognitive process involving the reader interacting with the text using various strategies to build meaning for the whole text. Sousa explains the cognitive process in detail. He described reading 
comprehension as a complex interactive process from knowing words, choosing meaning to context, understanding grammatical structure, generalizing to assessment (Sousa, 2017). Therefore, the reading process of comprehension starts with the understanding meaning of the words, and then the meaning of the sentences and the text structure as a result to get a better understanding of the text content.

The report of the National Reading Panel (NRP) in 2000 proposed that the important role of vocabulary learning to enhance the readers' reading comprehension. The NRP stated there is an interaction between readers and the text during the reading process and the teachers should be well prepared in strategy instruction to lead for better improvement in reading comprehension. In a follow-up study, RAND Reading Study Group (RRSG) points out three elements in the reading comprehension process which consist of the reader, the text and the activity of reading. The reader element consists of knowledge, abilities and experience that belong to the reader and the text element is the meaning of any written or electronic text. Meanwhile, the activity of reading includes the aim and processes, which relate to the act of reading. These elements are interrelated and influenced by sociocultural (Snow, 2002). Figure 1 shows the interrelation between the elements within a sociocultural context.

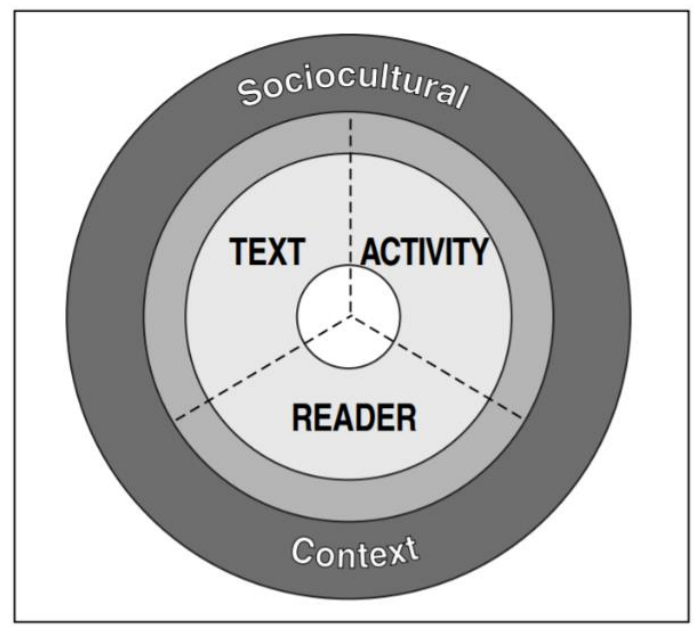

Figure 1. A Heuristic for Thinking about Reading Comprehension (Snow, 2002).

According to the Standard Curriculum for Primary Schools, Chinese language reading comprehension is more emphasising on the understanding of the whole text and get a holistic perception of the content. It will develop a sense of language in reading and express appreciation through the content of reading (KPM, 2018). For this purpose, the reading process involves a higher thinking ability. It requires the ability to make inference through the text, generates ideas, summarizes and provides evaluative views based on the content of reading.

With a deeper understanding of reading comprehension, it will help teachers implement effective teaching methods to teach students an appropriate reading strategy to maximize their comprehension capability. 
INTERNATIONAL JOURNAL OF ACADEMIC RESEARCH IN PROGRESSIVE EDUCATION AND

DEVELOPMENT

Vol. 9, No. 2, 2020, E-ISSN: $2226-6348 @ 2020$ HRMARS

\section{SQ3R Strategy}

The SQ3R strategy was introduced by Robinson in his book "Effective Study" in the year 1946. He is also known as "the grandfather of study strategies" (Asiri \& Momani, 2017). SQ3R has five steps and it is an abbreviation of Survey, Question, Read, Recite and Review. This systematic reading strategy enables students to have a better understanding and ability to remember the content of the text (Mustappa, 2017).

To suit the year four primary school students in using SQ3R for learning of Chinese comprehension, the SQ3R strategy was modified without changing the steps. At the first stage, Survey, students skimming the headlines, pictures, vocabulary and go through the text quickly to give students a broad picture of the content. Step two, Question, students need to generate questions base on the headline and the text which had been surveyed. In this stage, students can write down the questions on a piece of paper or refer to the questions are provided in the textbook. Step three, Read, students read slowly and try to find answers to the questions that have been listed. Students do remark on the textbook or write down the answer on the paper. Step four, Recite. In this step, students work in pairs. Students recite orally to their peers without refer to the textbook. Then, the students will get feedback from their peers after reciting. This step entails students recall the information from the memory when they are interacting between themselves. Teachers will also have discussions with students to identify the correct answer of the questions. Step five, review, students had to look back at the textbook and repeat the Read step to find the correct answer to the question. Students need to correct the wrong answer and review it again. The answer sheets can be as notes to review for a better understanding of the text.

Numerous studies have been carried out on the use of SQ3R strategy in different language disciplines lately. Recent studies (Jannah, 2019; Zhang, 2018; Rahman, 2017; Hu, 2016) have shown that SQ3R strategy is an effective way in improving students' comprehension including Chinese, Arabic, Indonesian and English languages. However, most of the studies have been carried out overseas and these studies have not been able to determine the efficacy of SQ3R strategy in Malaysia due to different contexts. The studies in Malaysia on the use of SQ3R strategy in reading comprehension is very less and limited. Mustappa (2017) used the quasi-experimental design in his study found that there were significant differences in achievement of Malay language comprehension between the experimental groups using the SQ3R technique and the control group.

Hence, the use of the SQ3R strategy needs to be implemented in Chinese comprehension at primary school settings to evaluate the efficacy of SQ3R strategy in improving students reading comprehension capability.

\section{Flipped Classroom Model}

The rise of information and communication technology (ICT) has set off a new era of teaching methods and this leads to the existence of Flipped Classroom. The Flipped Classroom was introduced beginning in the mid-2000s (Lage, Platt \& Treglia, 2000) and has been popularized 
by chemistry teachers Jon Bergman and Aaron Sams. Bergmann and Sams (2012) have begun to practice flipped teaching by recording their lectures and post them online for the students who have missed out on their classes. Surprisingly, the students gave a good response after watching the videos and engage themselves actively out of the classroom learning environment.

Flipped classroom leads the changes in conventional teaching method and promotes learning process occurring outside of the school (Smallhorn, 2017). Sousa (2017) stated that the term "Flipped" as a reverse process which it reverses the role of traditional teacher-centered to the student-centered learning. Bergmann and Sams (2012) in the book titled "Flip Your Classroom: Reach Every Student in Every Class Every Day" point out that the flipped classroom is more flexible and it depends on the teacher's creativity in conduct flip learning according to the circumstance and the students' ability. Nederveld and Berge (2015) stated that flipped classroom approach is not just about watching lectures through video outside the classroom and doing homework in the classroom. He emphasizes the classroom learning had to be more optimized by focusing on student- centered learning. In this situation, Hwang, Lai, and Wang (2015) suggested teachers need to be well prepared to develop the teaching materials through some interesting learning activities.

Flipped classroom is a model that rearranges time inside and outside of the classroom which will focus more on the students' learning process. Students had to complete the pre-class tasks given by the teacher. This will ensure the students prepare for the incoming lesson and acquire the basic knowledge in advance. During the contact time in class, students will be devoted more to meaningful activities involving higher thinking skills with collaboration with their peers.

Several researchers had established their own flipped classroom model based on the learning outcomes and the content of teaching materials to suit the students' needs. On the contrary, some of the studies had adopted or adapted the other researchers' Flipped Classroom Model. Hu (2015) established a flipped class model that transforms the conventional teaching model. The findings revealed a positive attempt to implement the flipped class model in teaching Chinese reading in primary school. Ahmad (2017) adopt Enfield's flipped classroom model in pedagogical module development based on reflective learning. The results of the study indicate that pedagogical modules effective in helping the students connect the skills with knowledge. Osman, Jamaludin, Yusoff and Jasni (2016) had adapted the FLIPPED model by Chen et al. (2014) as the procedure to conduct the flipped classroom for Malaysian Polytechnic students. However, this case study results in contrast to previous studies. Conversely, Osman et. al. (2016) reported no significant difference in effectiveness between student interaction and engagement in the flipped classroom on student achievement in the adjustment account topic.

Most of the previous studies have used the flipped classroom model in higher education and flipped learning is not widely implemented in Malaysia (Ahmad, 2017; Soon, Razak, \& Tah, 2017). However, the KPM's efforts to support the implementation of the flipped classroom has shown a strong commitment. From the launch of Frog VLE in 2012 and replaced by Google 
Classroom in 2019, KPM encourage the teachers and students to use Google Classroom as a virtue learning (KPM, 2019). Hence, this current study will propose a teaching method in the flipped classroom model to supports 21st-century learning by encouraging students to learn actively and acquire lifelong learning skills.

\section{Conceptual Framework}

A systematic framework is designed to explain the implementation of SQ3R strategy in the flipped classroom model. The framework will be a guideline to ensure the learning of Chinese reading comprehension is followed by the procedure even the learning occurred outside of the classroom without the teacher's full supervision.

Chinese reading comprehension learning in the flipped classroom model will be conducted in two phases, which are outside the classroom and inside the classroom. The phase outside the classroom requires the student to have internet access to do self-learning. The video uploaded to the internet is related to the text that will be taught inside the classroom. Students will use Google Classroom as the Learning Media Service (LMS) for online learning. Students will watch the video that uploaded to Google Classroom by the teacher and use SQ3R strategy during the learning process.

Firstly, students made an overview of the video and then generate some questions based on the video. Then, students will play again the video and watch it intensively to find the answer of the questions. Students will be asked to complete the quiz in Google Classroom whereby the questions are on the basic level of remembering and understanding. Students will get feedback from the quiz about their performance. From the quiz, the teacher will able to monitor the students' progress. Students need to watch again the video and to correct the wrong answer in the quiz.

While, for the reading process in phase two, which is conducted inside the class will involve the students in higher level thinking skills. Students need to analyses, make inferences, summarize, give own judgement and opinion about the text. As using the SQ3R strategy in reading, students have to skim the title, picture and text. Based on the skimming, students write down the questions. Students need to read carefully and find the answers. While reading, students analyze the text too. Students can underline the main idea or do summarizing on it. One of the features of the flipped classroom model is the collaboration between peers and teachers. Thus, in the Recite stage, students will comment on each other answers and discuss the correct answers. Discussion with the teacher will be conducted in this stage as well. In the last step, students reread the textbook and correct the wrong answers. The conceptual framework of this study is illustrated in Figure 2 to provide guidelines in integrate SQ3R strategy in the flipped classroom model. 


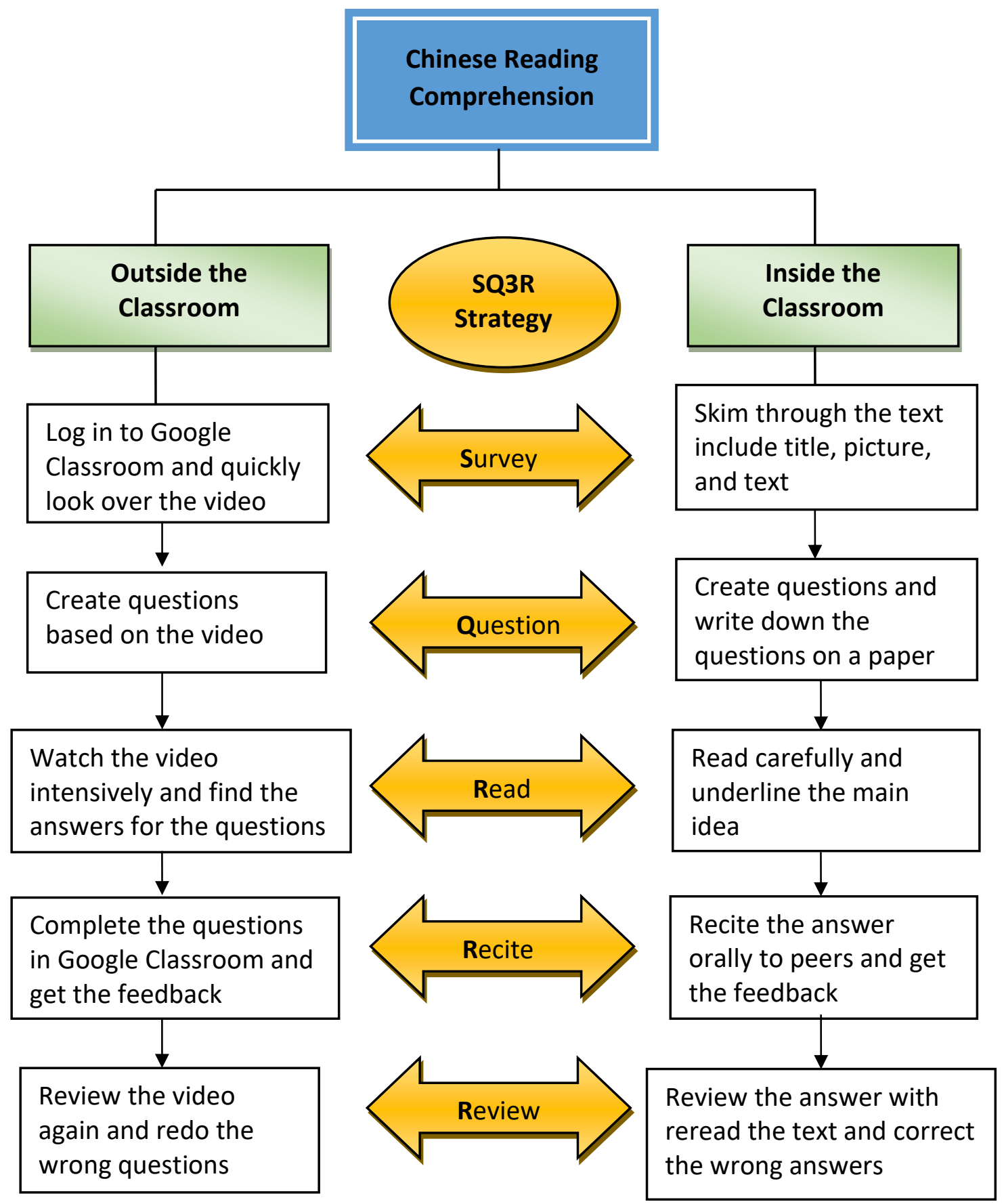

Figure 2. Conceptual framework of the integration SQ3R strategy in the flipped classroom model

\section{Methodology}

The purpose of the present study is to introduce the implementation of SQ3R strategy in the Flipped Classroom Model for Chinese reading comprehension. The study intends to use cross 
sectional survey design in examining students' perception of integration SQ3R in Flipped Classroom Model.

A total of 118 year four students from three different primary school in Klang district will be recruited for this study which is using purposive sampling technique. Data will be obtained from the respondents using a questionnaire and structured interview. The quantitative data generated will be analysed by using Statistical Package for Social Science (SPSS) version 23 to obtain the descriptive statistics. The descriptive statistics in this study will include percentage distribution, mean and the frequency counts.

\section{Conclusion and Discussion}

To improve the existing teaching strategy of reading, the researcher has introduced the SQ3R strategy with the integration of technology. The use of technology can change the existing learning environment become more interesting while the reading strategy is a useful skill for students to become independent readers.

This study has embedded literature on reading comprehension, SQ3R strategy and flipped classroom model as the support for the framework. This study set out to provide a systematic framework to apply SQ3R strategy in the flipped classroom model for Chinese reading comprehension at primary school. The present study will serve as a fundamental for future studies and as a reference for teachers who want to integrate a reading strategy with the help of technology in a new teaching paradigm.

The 'Flipping SQ3R strategy' is a suggested solution and possible be a better practice to improve the students' reading comprehension skill. Consequently, future empirical experimental studies can be done to investigate the effectiveness and accessibility of the SQ3R strategy in the flipped classroom model.

\section{Acknowledgement}

Our special thanks go to Sultan Idris Education University (UPSI). The first author would like to express special of gratitude to Ministry of Education Malaysia for the master scholarship. We would also like to extend our gratitude to all the committee members of ICASREMS 2020.

\section{Corresponding Author}

Chew Moi Fong

Faculty of Languages and Communications

Universiti Pendidikan Sultan Idris

Perak Malaysia.

Email: icenwai@yahoo.com 
INTERNATIONAL JOURNAL OF ACADEMIC RESEARCH IN PROGRESSIVE EDUCATION AND

DEVELOPMENT

Vol. 9, No. 2, 2020, E-ISSN: $2226-6348$ @ 2020 HRMARS

\section{References}

Abdullah, M. Z., \& Mamat, M. (2018). The Effects of Flipped Classroom Instructions on Student's Motivation in Algebraic Component. Jurnal Pendidikan Sains dan Matematik Malaysia, 8(2), 10-26.

Abu, M. H., Ali, M. J., \& Khairul, M. Y. (2001). Management Accounting. Journal of Accounting, 42(1), 234-245.

Ahmad, Z. (2017). Pembangunan Modul Pedagogi Kelas Berbalik Berasaskan Pembelajaran Reflektif untuk Politeknik Premier. Universiti Malaya.

Asiri, A., \& Momani, M. M. (2017). The Effectiveness of Using SQ3R to Teach Reading Skills. Asian Journal of Educational Research Vol, 5(1).

Bergmann, J., \& Sams, A. (2012). Flip Your Classroom: Reach Every Student in Every Class Every Day. USA.

Chen, Y., Wang, Y., \& Chen, N. S. (2014). Is FLIP Enough? Or should We Use the FLIPPED Model Instead? Computers \& Education, 79: 16-27. DOI 10.1016/j.compedu.2014.07.004.

Chew, E., Jones, L. J. N., \& Wordley, S. (2018). “Flipping or flapping?” Investigating Engineering Students' Experience in Flipped Classrooms. On the Horizon, 26(4), 307-316. https://doi.org/10.1108/OTH-04-2017-0014

Eunice Kennedy Shriver National Institute of Child Health. (2000). Report of the National Reading Panel: Teaching Children to Read (00-4769). Retrieved from https://www.nichd.nih.gov/publications/pubs/nrp/smallbook

Hu, M. L. (2016). 初中语文阅读策略教学研究 (The Research of Junior Middle School Language of Literature Reading Strategies Teaching). Southwest University.

Hu, Y. Q. (2015). 翻转课堂教学模式在小学语文阅读教学中的应用研究 (The Flipped Class Model in the Application of Primary School Chinese Reading Teaching Research). Fujian Normal University.

Hwang, G. J., Lai, C. L., \& Wang, S. Y. (2015). Seamless Flipped Learning: A Mobile TechnologyEnhanced Flipped Classroom with Effective Learning Strategies. Journal of computers in education, 2(4), 449-473.

Jannah, M. (2018). The Effect of Survey, Question, Read, Recite, and Review (SQ3R). International Research Journal of Engineering, IT \& Scientific Research, 4(1), 1-11.

Kementerian Pendidikan Malaysia. (2018). Dokumen Standard Bahasa Cina Tahun 4. Putrajaya: Bahagian Pembangunan Kurikulum.

Kementerian Pendidikan Malaysia. (2019, Jun 27). Kenyataan Media: Perkhidmatan Talian Internet di Sekolah. Retrieved from

https://www.moe.gov.my/en/pemberitahuan/media-statement/kenyataan-mediaperkhidmatan-talian-internet-di-sekolah

Lage, M. J., Platt, G. J., \& Treglia, M. (2000). Inverting the classroom: A gateway to Creating an Inclusive Learning Environment. The Journal of Economic Education, 31(1), 30-43.

Luo, Y. (2018). The Investigation about the Current Situation of Utilizing the Reading Strategies and Suggestions for the Teaching-Taking the Optics Valley Fifth Primary School in Wuhan as an Example. Central China Normal University.

Mustappa, W. D. W. (2017). Keberkesanan Teknik Membaca SQ3R dalam Pengajaran Kefahaman Membaca di Sekolah Menengah. Jurnal Pendidikan Bahasa Melayu, 7(1), 1-10. 
Nederveld, A., \& Berge, Z. L. (2015). Flipped learning in the workplace. Journal of Workplace Learning, 27(2), 162-172. https://doi.org/10.1108/JWL-06-2014-0044

Osman, S. Z. M., Jamaludin, R., Yusoff, W. M. W., \& Jasni, N. F. A. (2016). FLIPPED: A Case Study in Fundamental of Accounting in Malaysian Polytechnic. Journal of Education and eLearning Research, 3(1), 23-31.

Pamungkas, S., \& Suhardi, S. (2019). The ilnfluence of Cooperative Intergerative Reading and Composition (CIRC) and Survey, Question, Read, Recite, Review (SQ3R) on Ability Reading Comprehension of Elementary School. KnE Social Sciences, 546-556. https://doi.org/10.18502/kss.v3i17.4682

Rahman, I. A. (2017). The Implication of Teaching Method and Student's Schema Through Reading Comprehension on Facing Asean Economic Community. In Proceedings Education and Language International Conference, 1(1).

Santi, K. L., \& Reed, D. K. (2015). Improving Reading Comprehension of Middle and High School Students (vol. 10). Switzerland: Springer International Publishing.

Singh, S., \& Mishra, S. (2016). Positive Influence of the Multimedia in Primary Education. The International Journal of Indian Psychology, 3(2), 179-183.

Snow, C. (2002). Reading for Understanding: Toward an R\&D Program in Reading Comprehension. Santa Monica, CA: RAND Corporation

Soon, Y. L., Razak, M. S. S. A., \& Tah, M. S. (2017). An Exploratory Study in Flipped Classroom. Journal of Science and Mathematics Letters, 5, 52-62.

Sousa, D. A. (2017). How the brain learns (5th ed.). Thousand Oaks, CA: Corwin.

Wang, Y. (2018). A Case Study on Chinese Reading Teaching in Senior Grades of Primary School from the Perspective of Students' Understanding. Northeast Normal University.

Zhang, Y. (2018). 基于SQ3R的初中生英语名著阅读教学应用研究 (Application Research on Reading Teaching of English Masterpieces of Junior Middle School Students Based on SQ3R). China Academic Journal Electronic Publishing House, 53.

Zhang, Z. Z. (2017). Announcement of UPSR's Result. Orientaldaily. Retrieved from https://www.orientaldaily.com.my/news/nation/2017/11/23/221468 